Students' Views of Retail Employment

- Key Findings from Generation Ys

ADELINA M. BROADBRIDGE*,

GILLIAN A. MAXWELL**, SUSAN. M. OGDEN** 


\section{Students' Views of Retail Employment \\ - Key Findings from Generation Ys}

\section{Structured abstract}

Purpose: the aim of this article is to highlight some preliminary findings regarding students' perceptions of retail employment. It concentrates on those students who belong to Generation $\mathrm{Y}$, those born between 1977 and 1994.

Methodology: the research instrument consisted of a questionnaire survey administered to business studies students at two Scottish universities - Glasgow Caledonian University and Stirling University. This article reports on responses to 340 of these questionnaires - those students who already have some experience of retail employment, mainly as their part-time employment experiences while studying for their degree.

Findings: retail employment experience is common with the majority of students. Their expectations for future retail employment after graduation is to enjoy their work, while they are also concerned with fairness, equality and tolerance from their future employment.

Practical implications: the results are of benefit to retail employers' as preliminary indications of how they can attract potential graduate entrants into the sector. They provide some areas that retail companies should be addressing in their recruitment literature. These factors include future career opportunities including opportunities for self development, training and development, as well as pay and job security. Other factors that are also important to highlight are responsibility and challenging work opportunities and the maintenance of a good work-life balance.

Originality/value: this is an under-researched topic in the area of retail employment and Generation Y.

Keywords: retail, employment, Generation Y, expectations, students 


\section{Students' Views of Retail Employment \\ - Key Findings from Generation Ys}

\section{Introduction}

This article reports on the key findings of a recent survey of undergraduate students on their retail employment experiences and retail career expectations. The surveyed students were born in the period 1977 to 1994, so are part of the so-called Generation Y. This is a generation with distinct characteristics which have implications for their recruitment into, and career development in, full time work (Braid, 2007; Martin, 2005; Morton, 2002). As graduate recruitment and retention in retailing is an exigent issue (Broadbridge et al., 2007), the survey findings have particular import in the context of UK retailing.

Conducted in mid-2007 in the business schools of two universities in Scotland (Stirling University [SU] and Glasgow Caledonian University [GCU]), the purpose of the survey is to investigate how the theoretical characteristics of Generation $Y$ are manifest among people of this generation before they embark on their full time careers. The characteristics span personal values, employment terms and conditions, management approach and organisational culture, and personal career development. These four categories were identified in an earlier, exploratory stage of the authors' study of Generation Y (ibid; Broadbridge et al., 2006). Appendix 1 details the characteristics in each of the categories.

In total 486 undergraduate students participated in the study. As Table 1 shows, students were sampled from across levels years one to four, with a response rate of 91 per cent, and representing approximately 42 per cent of the student population for the modules sampled in the survey. Of the 486 students completing the survey, nine students were over the age of 30 and so have been excluded from the analysis.

$<$ Table 1 about here $>$ 
Seventy five per cent of the respondents indicated that they had experience of working in the retail sector and it is the responses of these 340 students that are the subject of this article. These students have an average age of 20 and 67 per cent are female, in keeping with the general profile of students in the business schools. They are registered on a range of courses with 27 per cent studying retail or marketing degrees, 28 per cent undertaking general business studies degrees, 20 per cent studying sector specific degrees such as tourism, hospitality or leisure, and the remaining 25 per cent studying a range of programmes relating to finance, IT, law or journalism. As Figure 1 shows, the response sample is reasonably evenly distributed by level of study, with 26 per cent of respondents in level one, 24 per cent in level two, 30 per cent in level three, and 21 per cent in level four (Scottish honours level).

$<$ Figure 1 about here>

The key survey findings from these respondents are reported below in terms of employment experiences and employment expectations.

\section{Employment Experiences}

Just under two-thirds of students (64 per cent) who have worked in retail report that this is the sector where they have most employment experience. The remaining one-third (34 per cent) have more experience of working in other sectors and, therefore, have a source of comparison in their views on the attractiveness of the retail sector. As Table 2 shows, most of this experience comes from working in various parts of the hospitality sector (18 per cent), that is, bars, restaurants or cafes and hotels. This reflects the findings of a recent report that suggests that 'Generation $\mathrm{Y}$ adults are much more likely than adults in general to be working in service industries, especially distribution, hotels and restaurants' (Keynote, 2007: 20). The report suggests that almost 40 per cent of all Generation $Y$ adults work in the services sector due to the plentiful supply of part-time jobs that are suitable for students, and to the availability in the retail sector of lower skilled, full-time jobs for younger workers with fewer qualifications or experience. 
$<$ Table 2 about here $>$

Students provided feedback on the quality of their work experiences, on a scale where $1=$ very negative and $5=$ very positive. As Table 3 shows, almost half (49 per cent) of all students report having very positive or mostly positive experiences at work, with a further 45 per cent reporting a mix of positive and negative experiences. Only a small proportion, (6.2 per cent) report very or mostly negative experiences. These findings are important in that poor experiences of retailing can have a detrimental impact on views of retail careers (Broadbridge, 2003), whereas good experiences can have a positive impact (Retail Merchandiser, 2003).

Table 3 also shows that there is little difference between the mean scores in relation to measuring the perceptions of the quality of the work experience between students who have most experience of retail compared with those who have most experience of other sectors. However, a slight difference can be discerned in relation to the level of positive experiences. For those with most experience of retail, the number of students with mostly or very positive views drops to 45 per cent, compared to 56 per cent for those students with most experience in other sectors. In contrast, the difference between these two subcategories for negative/very negative experiences is only two per cent (seven per cent for most experience of retail and five per cent for most experience of non-retail).

$<$ Table 3 about here>

The students' opinions on their employment experience are likely to have a concomitant effect on their views of the attractiveness of working in the sector after graduation. Table 4 illustrates the findings on this. Of those students with work experience in retailing, 24 per cent consider retail is quite or very attractive, 28 per cent a little attractive and 28 per cent that the sector is totally unattractive. One interpretation of these figures is that just over half of all students who have worked in retail (52 per cent) could be potential recruits into the sector, an encouraging finding in 
the light of earlier studies which point to difficulties in attracting good quality managers in retailing (Commins and Preston, 1997). Furthermore, while one-quarter of students with retail experience would actively seek retail jobs, it could be argued that the other quarter, the 'career floaters,' could be persuaded by the right job or the right conditions to work in retail. For Generation Ys, this may mean satisfying their drive for career success, security, opportunity and responsibility (Kerslake, 2005).

\section{$<$ Table 4 about here $>$}

A deeper analysis of the attractiveness of retailing post-graduation was conducted in order to assess if there is a gendered aspect, as there is for example in prospects for females' career development to management (Maxwell and Ogden, 2006). The next table, Table 5, disaggregates the data on these lines. In addition, a chi-square test was run, yielding a ' $p$ ' value of 0.284 , which indicates no statistical difference in perceptions by gender.

$<$ Table 5 about here $>$

\section{Employment Expectations}

As with the survey questions on employment experiences, the questions on students' employment expectations were framed from the authors' earlier work on the characteristics of Generation Y (Broadbridge et al., 2007). In particular, the survey was designed to identify students' priorities as regards the importance they attach to their personal values in employment. Other studies have found that early career is a distinct stage of work needs (Sturges and Guest, 2004) and career management (Sturges et al., 2002).

For personal values, students were asked to express their level of agreement or disagreement with ten statements wherein $1=$ strongly disagree, $2=$ disagree, $3=$ neither agree nor disagree, 4 $=$ agree, and $5=$ strongly agree. Table 6 shows the results in order of priority for all of the 
respondents. Four characteristics are evident in the agree to strongly agree mean (4 -5). Of these, above all, the respondents' want enjoyment from their work (mean of 4.76). Notably, the other three characteristics concern the interlinked areas of fairness, equality and tolerance. Although it has been noted that these are important, professionally and personally, to Generation Ys (Morton, 2002), this finding contradicts that of the authors in the earlier stage of their work when the areas were not raised at all by the informants (Broadbridge et al., 2007).

$<$ Table 6 about here $>$

Moreover, the data were collapsed into a three by two table (where the two categories of agreement were collapsed into one, and similarly, the two categories of disagreement were collapsed into one) so that a more reliable chi-square test could be undertaken to see if there is a relationship between gender and employment expectations. This found four significant differences (i.e. where $p<0.05$ ) of gendered responses, as highlighted in bold in Table 6 . Further analysis of where differences lie between males and females shows that, perhaps surprisingly, proportionately more males than females disagree with the statement 'my career is as important as my home life', although overall only 24 per cent of all respondents disagreed/strongly disagree with the statement. Just over one-third (38 per cent) of all respondents agree/strongly agree that 'time-off is more important than financial reward', and, again, proportionally more males than females either strongly disagree or disagree with this statement, indicating their higher desire for financial rewards. In relation to the statement, 'I want to work with employers who are fair to all employees', more males than females expressed no strong view indicating their ambivalence. Whilst the vast majority of respondents (74 per cent) agreed or strongly agreed with the statement 'I want to work with a diverse group of people in my career,' a higher proportion of males than females disagree or have no strong views, perhaps indicating that women are more interested in diversity issues than men. Lastly, Table 6 provides further scrutiny in relation to overall level of agreement through standard deviations. What is evident here is that there is a high level of collective agreement across the top four priorities especially as it is in these that the standard deviations are lowest. 
Moving on to the other Generation Y characteristics of employment terms and conditions, management approach and organisational culture, and personal career development (again as detailed in Appendix 1), students were surveyed on their views on these in the first stage of their careers following graduation. They were asked to rate a range of 37 factors in relation to their level of importance. Table 7 shows these factors listed in order of mean importance, as ranked by the mean score where $1=$ totally unimportant and $5=$ very important. The ten factors with the highest means are highlighted.

As can be seen, the first two factors - determination to succeed (Kerslake, 2005) and meeting personal goals (Eisner, 2005) - concern personal career development. Indeed, personal career development factors are the most dominant in the 15 factors that have a mean over 4.0, with seven of the 15 relating to this category. That this is the case strongly suggests that students appear to accept that responsibility for their career success is primarily theirs, upholding a protean (Hall and Mirvis, 1996) attitude towards their career. At the same time, the employment terms and conditions of good pay (Morton, 2002), opportunities for training and development (Broadbridge et al., 2006) together with the management approach and culture feature of supportive managers (Martin, 2005) are all included in the top 10 factors. These findings point to the importance the respondents attach to seeking appropriate rewards, development and treatment by managers in the pursuit of their careers.

At the bottom end of the table, of least importance to the respondents are working long hours (Broadbridge, 2002) with a mean of 2.87 and moving companies for career development (Baruch, 2004) with a mean of 2.9. The relative unimportance of moving companies combined with the relative importance of clear company goals and promotion path (both with means of 4.09) stands at odds with Baruch's (2004) contemporary model of career development by short-term, transactional relationships with employers. Instead it reflects the traditional career structure (Holbeche, 2003) and desire for internal promotion (Broadbridge et al., 2006). However, the 
finding that work-life and personal sacrifices are unimportant in early careers accords with other studies (Sturges et al., 2002; Sturges and Guest, 2004).

\author{
$<$ Table 7 about here $>$
}

That stated, as the standard deviations in Table 7 indicate, the respondents' views are among the widest as regards working long hours and sacrifice of work-life balance. The widest difference, with a standard deviation of 1.294, lies in the running own businesses factor (Martin, 2005). The narrowest difference in opinions is found in opportunities for training and development (Broadbridge et al., 2006). Interestingly, this factor emerged as the only factor with a significant chi-square score $(p=0.03)$ when the factors in Table 7 were analysed by gender; proportionately more males consider this factor more important than females.

\title{
Conclusions
}

These initial survey findings provide insight into Generation Y students' views of retail employment, extending the development theory on this group of young people. They reinforce that student retail employment is common. Moreover, the Generation $\mathrm{Y}$ business student group is arguably a valuable labour market as about half of it may translate into graduate entrants embarking on careers in retailing. The survey suggests that such Generation $Y$ recruits will bring with them not only retail experience but also expectations of enjoying their work, fairness, equal opportunities and tolerance of difference in people they work with. Though clearly important to both genders overall, evidently the personal values of fairness and diversity tend to more important to females than males. Also, the findings infer that there may be a tendency for females more than males to value their home life and time off. Further, a key implication of the survey findings is that Generation Ys embarking on their careers will assume personal responsibility for focusing on and driving their career success. At the same time, they have particular employer 
expectations of good pay, training and development opportunities, and supportive managers. Training and development opportunities have a heightened importance for the male respondents.

These findings deepen understanding, so inform the management, of Generation Ys in retailing. Moreover, in the gendered differences that emerge in the findings, they indicate that there is diversity among Generation Ys. In short, Generation $Y$ has distinction as a group and within its group. 


\section{References}

Baruch Y. (2004) Managing Careers: Theory and Practice, London: FT Prentice Hall.

Braid M. (2007) 'Why today's graduates don't make the grade,' The Sunday Times, February 25, p7.

Broadbridge, A. (2002) 'Retail Managers: Their Work Stressors and Coping Strategies' Journal of Retailing and Consumer Services, 9 (3):173-183.

Broadbridge A. (2003) 'Student Perceptions of Retailing as a Destination Career,' International Journal of Retail and Distribution Management, 31(6), pp298-309.

Broadbridge A., Maxwell G. and Ogden S. (2006) 'Generation Y's Experiences, Perceptions and Expectations of Employment in UK Retailing: Framing a Longitudinal Study' (development paper) British Academy of Management Annual Conference, Belfast, September.

Broadbridge A., Maxwell G. and Ogden S. (2007) '13_2_30: Experiences, Perceptions and Expectations of Retail Employment for Generation Y', Career Development International, 12(6).

Commins J. and Preston D. (1997) 'The Attractiveness of Retailing as a Career for Graduates: An Update,' International Journal of Retail and Distribution Management, 25(4), pp120-125.

Hall, D.T. and Mirvis, P.H. (1996) 'The New Protean Career: Psychological Success and the Path with a Heart', in: Hall, D.T. (Ed.) The Career is Dead - Long Live the Career. San Francisso: Jossey-Bass.

Holbeche L. (2003) Aligning HR and Business Strategy, Oxford; Butterworth-Heinemann.

Kerslake P. (2005) 'Words from the Ys,' Management, May, pp44-46.

Keynote (2007), 'Generation Y Market Assessment', Keynote Ltd.

Martin C. (2005) 'From High Maintenance to High Productivity: What Managers need to Know about Generation Y,' Industrial and Commercial Training, 37(1), pp39-44.

Maxwell G. and Ogden S. (2006) 'Career Development of Female Managers in Retailing: Inhibitors and Enablers', Journal of Retailing and Consumer Services, vol. 13 issue 2, pp111-120.

Morton L.P. (2002) 'Targeting Generation Y,' Public Relations Quarterly, Summer, pp46-48. Retail Merchandiser (2003) 'Retail Employers Must Understand Gen Y Values,' 43(2), p12.

Sturges J. and Guest D. (2004) 'Working to live or living to work? Work-life balance early in the career', Human Resource Management, 14(4), start page 5.

Sturges J., Guest D., Conway N. and Mackenzie Davey K. (2002) 'A longitudinal study of the relationship between career management and organisational commitment among graduates in the first ten years at work,' Journal of Organisational Behaviour, 23(6), start page 731. 
Table 1 Student Survey Participation, by level

\begin{tabular}{|c|c|c|c|c|}
\hline $\begin{array}{l}\text { LEVEL/ } \\
\text { YEAR }\end{array}$ & $\begin{array}{l}\text { Student module } \\
\text { numbers }\end{array}$ & $\begin{array}{l}\text { Students } \\
\text { sampled }\end{array}$ & $\begin{array}{l}\text { No of } \\
\text { Responses }\end{array}$ & $\begin{array}{l}\text { Total } \\
\text { participation }\end{array}$ \\
\hline \multirow[t]{2}{*}{ Level 1} & $200(\mathrm{SU})$ & 78 & 78 & \multirow[t]{2}{*}{$160(33 \%)$} \\
\hline & 300 (GCU) & 90 & 82 & \\
\hline \multirow[t]{2}{*}{ Level 2} & 114 (SU) & 71 & 71 & \multirow[t]{2}{*}{$124(26 \%)$} \\
\hline & 200 (GCU) & 55 & 53 & \\
\hline \multirow[t]{2}{*}{ Level 3} & 90 (SU) & 45 & 39 & \multirow[t]{2}{*}{$117(24 \%)$} \\
\hline & 82 (GCU) & 80 & 78 & \\
\hline \multirow[t]{2}{*}{ Level 4} & 35 (SU) & 35 & 8 & \multirow[t]{2}{*}{$85(17 \%)$} \\
\hline & 127 (GCU) & 80 & 77 & \\
\hline Totals & 1148 & 534 & 486 & 486 (42\%) \\
\hline
\end{tabular}

SU - Stirling University; GCU - Glasgow Caledonian University

Figure 1

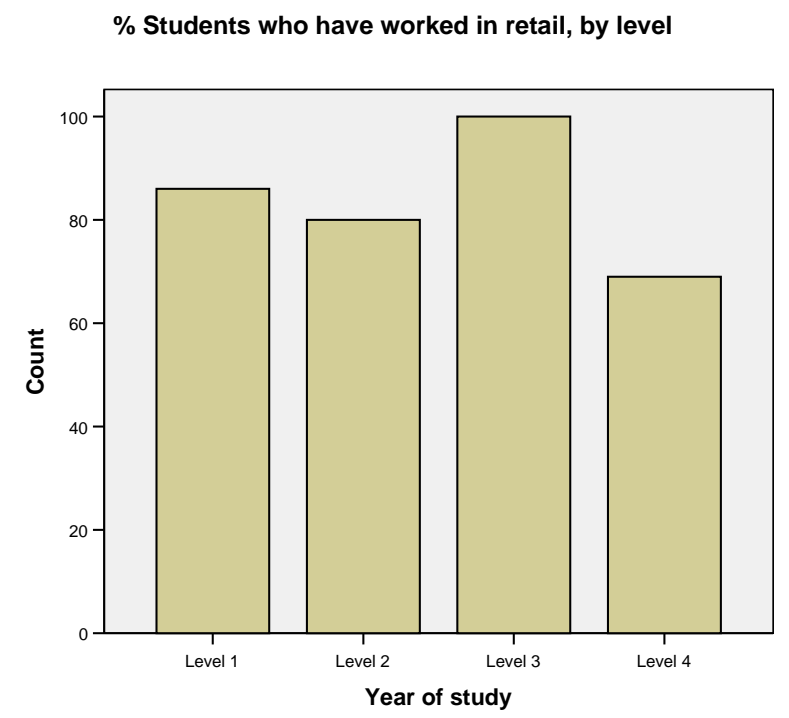


Table 2 Sector in which Students have Most Work Experience

\begin{tabular}{|ll|r|r|}
\hline & & \\
& & Frequency & Percent \\
\hline Valid & Retail & 216 & 63.5 \\
& Bar & 26 & 7.6 \\
& Restaurant/Café & 28 & 8.2 \\
Hotel & 8 & 2.4 \\
Leisure & 17 & 5.0 \\
Call Centre & 17 & 5.0 \\
Other & 28 & 8.2 \\
Total & 340 & 100.0 \\
\hline
\end{tabular}

Table 3 Quality of Work Experiences

\begin{tabular}{|l|r|r|r|}
\hline & $\begin{array}{c}\text { All students who } \\
\text { have worked in } \\
\text { retail }\end{array}$ & $\begin{array}{c}\text { Students with } \\
\text { most } \\
\text { experience of } \\
\text { retail sector }\end{array}$ & $\begin{array}{l}\text { Students with most } \\
\text { experience of NON- } \\
\text { retail sectors. }\end{array}$ \\
\hline Very negative & 1.2 & 1.4 & .8 \\
Mostly negative & 5.0 & 5.6 & 4.0 \\
Mix of positive \& negative & 45.0 & 48.1 & 39.5 \\
Mostly positive & 37.9 & 37.0 & 39.5 \\
Very positive & 10.9 & 7.9 & 16.1 \\
Total number of students & 340 & 216 & 124 \\
Mean & 3.52 & 3.44 & 3.66 \\
Standard Deviation & 0.8 & 0.776 & 0.825 \\
\hline
\end{tabular}

Table 4 Attractiveness of Retail Sector Following Graduation

\begin{tabular}{l|r|r|r|r|}
\hline & Frequency & Percent & Male & Female \\
\hline Totally unattractive & 95 & 27.9 & 25 & 69 \\
A little attractive & 95 & 27.9 & 31 & 62 \\
Neither attractive or & 67 & 19.7 & 24 & 43 \\
unattractive & 62 & 18.2 & 26 & 36 \\
Quite attractive & 21 & 6.2 & 5 & 16 \\
Very attractive & 340 & 100.0 & 111 & 226 \\
Total & & \\
\hline
\end{tabular}


Table 5 Relationship between Gender and Perceptions of Retail Attractiveness

\begin{tabular}{|c|c|c|c|c|c|c|}
\hline & \multicolumn{5}{|c|}{ Perception of Retail Attractiveness } & \multirow[t]{2}{*}{ Total } \\
\hline & $\begin{array}{c}\text { Totally } \\
\text { unattractive }\end{array}$ & $\begin{array}{c}\text { A little } \\
\text { attractive }\end{array}$ & $\begin{array}{l}\text { Neither } \\
\text { attractive or } \\
\text { unattractive }\end{array}$ & $\begin{array}{c}\text { Quite } \\
\text { attractive }\end{array}$ & $\begin{array}{c}\text { Very } \\
\text { attractive }\end{array}$ & \\
\hline Male & $25(23 \%)$ & $31(28 \%)$ & $24(22 \%)$ & $26(23 \%)$ & $5(4 \%)$ & 111 \\
\hline Female & 69 (31\%) & $62(27 \%)$ & 43 (19\%) & $36(16 \%)$ & $16(7 \%)$ & 226 \\
\hline Total & $94(28 \%)$ & $93(28 \%)$ & $67(20 \%)$ & $62(18 \%)$ & $21(6 \%)$ & 337 \\
\hline
\end{tabular}

Table 6 Priority Employment Expectations on Personal Values (in order of importance by mean score)

\begin{tabular}{|l|c|c|c|c|}
\hline & $\mathrm{N}$ & Mean & $\begin{array}{c}\text { Standard } \\
\text { Deviation }\end{array}$ & significance \\
\hline I want to enjoy my work. & 338 & 4.76 & .517 & $\mathrm{n} . \mathrm{s}$ \\
\hline $\begin{array}{l}\text { I want to work with employers } \\
\text { who are fair to all employees. }\end{array}$ & 334 & 4.64 & .623 & $(\chi 2 \quad 8.199 ; \mathrm{df}=2 ; \mathrm{p}=0.017)$ \\
\hline $\begin{array}{l}\text { I expect equal opportunities in my } \\
\text { career progression. }\end{array}$ & 338 & 4.52 & .723 & $\mathrm{n} . \mathrm{s}$ \\
\hline $\begin{array}{l}\text { I will tolerate differences in people I } \\
\text { work with. }\end{array}$ & 336 & 4.04 & .779 & $\mathrm{n} . \mathrm{s}$ \\
\hline $\begin{array}{l}\text { I work to live, rather than live to } \\
\text { work. }\end{array}$ & 337 & 3.98 & 1.052 & $\mathrm{n} . \mathrm{s}$ \\
\hline $\begin{array}{l}\text { I want to work with a diverse } \\
\text { group of people in my career. }\end{array}$ & 338 & 3.90 & .838 & $(\chi 2 \quad 12.697 ; \mathrm{df}=2 ; \mathrm{p}=0.002)$ \\
\hline $\begin{array}{l}\text { Personal sacrifices are necessary } \\
\text { to build my career. }\end{array}$ & 338 & 3.58 & .912 & $\mathrm{n.s}$ \\
\hline $\begin{array}{l}\text { My career is as important as my } \\
\text { home life. }\end{array}$ & 338 & 3.44 & 1.217 & $(\chi 2 \quad 10.275 ; \mathrm{df}=2 ; \mathrm{p}=0.006)$ \\
\hline $\begin{array}{l}\text { Time off is more important than } \\
\text { financial rewards. }\end{array}$ & 338 & 3.30 & 1.003 & $(\chi 2 \quad 6.445 ; \mathrm{df}=2 ; \mathrm{p}=0.04)$ \\
\hline $\begin{array}{l}\text { Money isn't everything in my } \\
\text { career. }\end{array}$ & 337 & 3.15 & 1.166 & $\mathrm{n} . \mathrm{s}$ \\
\hline
\end{tabular}


Table 7 Factors Important to Career Success after Graduation (ranked by mean scores)

\begin{tabular}{|c|c|c|c|}
\hline & $\mathrm{N}$ & Mean & Std. Deviation \\
\hline 1. Determined to Succeed & 339 & 4.48 & .786 \\
\hline 2. Personal goals & 338 & 4.39 & .756 \\
\hline 3. Good Pay & 339 & 4.34 & .807 \\
\hline 4. Self-development & 338 & 4.33 & .764 \\
\hline 5. Opportunities for Training and development & 338 & 4.26 & .741 \\
\hline 6. Supportive Managers & 338 & 4.25 & .814 \\
\hline 7. Job Security & 337 & 4.20 & .873 \\
\hline 8. Positive Company Culture & 337 & 4.19 & .826 \\
\hline 9. Clear Career Goals & 338 & 4.09 & .862 \\
\hline 10. Clear Promotion Path & 338 & 4.09 & .866 \\
\hline 11. Working Hard & 336 & 4.06 & .938 \\
\hline 12. Good work/life balance & 338 & 4.06 & .947 \\
\hline 13. Personal Responsibility & 337 & 4.03 & .914 \\
\hline 14. Challenging Work & 337 & 4.02 & .785 \\
\hline 15. Upwards promotion & 338 & 4.01 & .861 \\
\hline 16. Make a difference & 338 & 3.96 & .823 \\
\hline 17. Chance to be creative & 338 & 3.92 & .934 \\
\hline 18. Using their degree & 339 & 3.91 & .978 \\
\hline 19. Feedback from employers & 337 & 3.83 & .836 \\
\hline 20. Networking Skills & 338 & 3.80 & .939 \\
\hline 21. Flexible Hours & 339 & 3.76 & .954 \\
\hline 22. Feedback on personal performance & 335 & 3.76 & .808 \\
\hline 23. Good Pension Scheme & 334 & 3.75 & 1.020 \\
\hline 24. Gaining a higher entry point into organisation. & 337 & 3.74 & 0.907 \\
\hline 25. Gaining further qualifications & 336 & 3.67 & .998 \\
\hline 26. Formal graduate training scheme & 339 & 3.61 & 1.007 \\
\hline 27. Willingness to work in different locations & 338 & 3.58 & 1.114 \\
\hline 28. Being fast-tracked for promotion & 337 & 3.53 & 1.029. \\
\hline 29. Previous Sector Experience & 336 & 3.52 & .956 \\
\hline 30. Company loyalty (i.e. length of service) & 338 & 3.44 & .958 \\
\hline 31. Customer Facing Roles & 338 & 3.39 & 1.020 \\
\hline 32. Environment of Change & 334 & 3.22 & .987 \\
\hline 33. Running Own Business & 339 & 3.17 & 1.294 \\
\hline 34. Sacrifice of work-life balance & 338 & 3.15 & 1.008 \\
\hline 35. Personal Sacrifices & 338 & 3.12 & .976 \\
\hline 36. Moving companies & 338 & 2.90 & .904 \\
\hline 37. Working long hours & 337 & 2.87 & 1.038 \\
\hline
\end{tabular}


Appendix 1: $\underline{\text { Characteristics of Generation Y }}$

\begin{tabular}{|c|c|c|c|}
\hline $\begin{array}{l}\text { Employment Terms \& } \\
\text { Conditions }\end{array}$ & Management Approach \& Culture & Personal Career Development & Personal Values \\
\hline
\end{tabular}




\begin{tabular}{|c|c|c|c|}
\hline $\begin{array}{l}\text { sacrifice work-life } \\
\text { balance in short-term } \\
\text { for career gain } \\
\text { (Kerslake, 2005; } \\
\text { Broadbridge et al, } \\
\text { 2006) } \\
\text { Provision of training } \\
\text { opportunities } \\
\text { (Morton, 2002, } \\
\text { Broadbridge et al, } \\
\text { 2006) } \\
\text { career goals in } \\
\text { organisation } \\
\text { (Broadbridge et al., } \\
\text { 2006) } \\
\text { clear promotion } \\
\text { path (Broadbridge et } \\
\text { al., 2006) } \\
\text { working long } \\
\text { hours } \\
\text { (Broadbridge, } \\
\text { 2002) }\end{array}$ & $\begin{array}{ll}\text { employers (Foreman 2006) } \\
\text { - Thrive on change and uncertainty } \\
\text { (Harris 2006) }\end{array}$ & $\begin{array}{l}\text { freedom to perform (Eisner } \\
\text { 2005) } \\
\text { - } \quad \text { Strives to make a difference } \\
\text { (Eisner 2005) } \\
\text { - } \text { Having own business (Martin } \\
\text { 2005) } \\
\text { - } \\
\text { Desire to use knowledge } \\
\text { gained in degree } \\
\text { (Broadbridge et al, 2006) } \\
\text { - } \text { Prefer Head-office to } \\
\text { customer-facing jobs } \\
\text { (Broadbridge et al, 2006). } \\
\text { - } \text { Individual responsibility for } \\
\text { career (Hall \& Mirvis, 1996, } \\
\text { Broadbridge et al, 2006) } \\
\text { - Achievement oriented } \\
\text { (Eisner, 2005) } \\
\text { Taking personal } \\
\text { responsibility for career } \\
\text { (Broadbridge et al., 2006) } \\
\text { Less satisfied with jobs and } \\
\text { employers and more open to } \\
\text { leave for something better } \\
\text { (Eisner, 2005) } \\
\text { - Wants instant gratification } \\
\text { (Southard and Lewis, 2004) } \\
\text { Work experience } \\
\text { (Broadbridge et al., 2006) } \\
\text { willingness to work in } \\
\text { different locations } \\
\text { (Broadbridge et al., 2006) }\end{array}$ & $\begin{array}{ll}2006) \\
\text { Contributing to society (Allen, } \\
\text { 2004) } \\
\text { Enjoyment of work. } \\
\text { (Broadbridge et al 2006) } \\
\text { - Goal oriented (Southard \& } \\
\text { Lewis, 2004; Foreman, 2006) } \\
\text { Meeting personal goals (Eisner, } \\
\text { 2005, Broadbridge, et al, 2006). }\end{array}$ \\
\hline
\end{tabular}




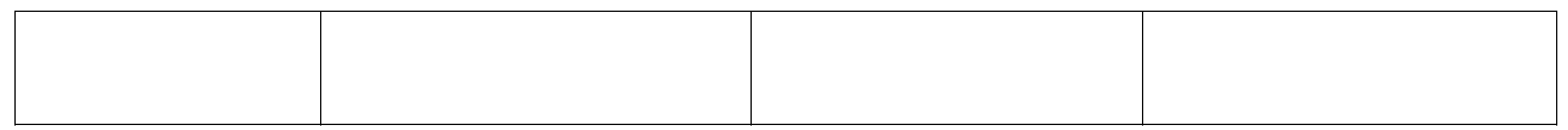


